\title{
Biomass enhancement in maize and soybean in response to glutamate dehydrogenase isomerization
}

\author{
G.O. OSUJI, A.S. MANGAROO, J. REYES, A. BULGIN and V. WRIGHT \\ Cooperative Agricultural Research Center, Prairie View A\&M University, Texas A\&M University System, \\ P.O. Box 4079, Prairie View, Texas 77446, USA
}

\begin{abstract}
The relationship between nutrient composition, crop biomass, and glutamate dehydrogenase (GDH) isoenzyme pattern was investigated in soybean (Glycine max) and maize (Zea mays) by monitoring the nutrient induced isomerization of the enzyme from the seedling stage to the mature crop. GDH was extracted from the leaves of the plants. and the isoenzymes were fractionated by isoelectric focusing followed by native polyacrylamide gel electrophoresis. The isomerization $\mathrm{V}_{\max }$ values for soybean GDH, similar to maize GDH increased curvilinearly from $200-400 \mu \mathrm{mol} \mathrm{mg}^{-1} \mathrm{~min}^{-1}$ as the inorganic phosphate nutrient applied to the soil decreased from $50-0 \mathrm{mM}$. In soybean, combinations of $\mathrm{N}$ and $\mathrm{K}, \mathrm{P}$, or $\mathrm{S}$ nutrients induced the acidic and neutral isoenzymes, and gave biomass increases $25-50 \%$ higher than the control plant. GDH isoenzymes were suppressed in soybean that received nutrients without $\mathrm{N}, \mathrm{K}$, or $\mathrm{P}$ and accordingly the biomass was about $30 \%$ lower than the control. Treatment of maize with NPK nutrients increased the GDH $V_{\max }$ values from 138.9 at the vegetative to $256.4 \mu \mathrm{mol} \mathrm{mg}{ }^{-1} \mathrm{~min}^{-1}$ at the reproductive phase, and suppressed the basic isoenzymes, but induced both the acidic and neutral isoenzymes thereby inducing seed production $(27.0 \pm 1.4 \mathrm{~g}$ per plant); whereas both the acidic and basic isoenzymes were suppressed in the control maize, and seeds did not develop. Simultaneous induction of the acidic, neutral, and basic isoenzymes of GDH indicated the occurrence of senescence. Therefore in maize and soybean, the induction of the acidic and basic isoenzymes of GDH led to the enhancement of biomass.
\end{abstract}

Additional key words: GDH-induced biomass, Glycine max, isoelectric focusing. nitrogen, phosphorus, potassium. sulfur. Zea mays.

\section{Introduction}

Glutamate dehydrogenase [GDH, EC 1.4.1.2] isomerizes in vitro in response to $\alpha$-ketoglutarate $(\alpha-K G)$ and NADH as substrates (Osuji et al. 2001), and also in vivo in response to the treatment of plants with nutrients (Osuji and Madu 1995, Hřib et al. 1997, Osuji and Madu 1997, Osuji et al. 1998, Osuji and Braithwaite 1999). Earlier biochemical and molecular studies had suggested the involvement of the amination activity of the enzyme in $\mathrm{NH}_{4}{ }^{+}$salvage (King and $\mathrm{Wu} 1971$, Duke et al. 1978, Jail and Srivastava 1981, Singh and Srivastava 1982, Jail and Shargool 1987, Lightfoot et al. 1988, Šukalović 1990, Magalhaes 1991, Melo-Oliveira et al. 1996, Turano et al. 1996). Demonstration of the non-proteolytic cleavage of the enzyme in vitro (Osuji et al. 2001) confirmed the chemical mechanism of the isomerization (Osuji et al.
1999). But the physiological function of the enzyme still remains unclear. Tobacco plants genetically transformed with the gdh gene produced more biomass than the control plants (Ameziane et al. 2000). The discovery of the biomass enhancement function and the description of the chemical basis of the isomerization have now set the stage for studies on the molecular mechanisms of the enzyme's function. Although the discovery of the biomass enhancement function moved the GDH controversy above and away from the discussions on the redox catalytic mechanism (Robinson et al. 1992, Osuji el al. 2001), the relationships between biomass production, $\mathrm{GDH}$ isoenzyme population distribution pattern, and plant nutrient supply have not been investigated. Neither has the isomerization of the enzyme from the seedling stage

Received 25 March 2002, accepted 19 November 2002.

Abbreviations: NPKS - nitrogen, phosphorus, potassium, and sulfur nutrients; GDH - glutamate dehydrogenase ; $\alpha-K G$ - $\alpha$-ketoglutarate; IEF - isoelectric focusing; PAGE - polyacrylamide gel electrophoresis; DAE - days after emergence.

Fax: (+93) 6857 2325, e-mail: godson_osuji@pvamu.edu 
to the mature crop been investigated. However, GDH also isomerizes in response to plant senescence (Watanabe et al. 1997, 1989) arising from the re-mobilization of nitrogen derived from protein hydrolysis (Zimmerman 1960 ). Changes in GDH isoenzyme distribution patterns that are induced by the senescence (Loulakakis et al. 1994) of leaves have not been experimentally delineated from those induced by mineral nutrients so as to understand those isomerizations that define the biomass of plants. The results presented hereunder show that the

\section{Materials and methods}

Isomerization of GDH: Maize (Zea mays L. hybrid KD-68) and soybean (Glycine max L. cv. Donegal) seeds were sowed in $10-\mathrm{dm}^{3}$ pots containing 9:1 mixture of sand:vermiculite, and watered with distilled water (control) or with solutions of $\mathrm{N}, \mathrm{P}$ and $\mathrm{K}$ nutrients in single, and in combination at different ratios $(5,25,50$, $75,100 \mathrm{mM} \mathrm{NH}_{4} \mathrm{Cl}$ solutions; $\mathrm{N}_{1} \mathrm{P}_{1} \mathrm{~K}_{1}$ solution containing $6 \mathrm{mM} \mathrm{NH}_{4} \mathrm{Cl}, 2 \mathrm{mM} \mathrm{KCl}$, and $2 \mathrm{mM} \mathrm{KH}_{2} \mathrm{PO}_{4} ; \mathrm{N}_{1} \mathrm{P}_{0} \mathrm{~K}_{1}$ solution containing $2 \mathrm{mM} \mathrm{NH}_{4} \mathrm{Cl}$ and $4 \mathrm{mM} \mathrm{KCl}$; $\mathrm{N}_{0} \mathrm{P}_{1}, \mathrm{~K}_{0}$ solution containing $3.5 \mathrm{mM} \mathrm{Na} \mathrm{HPO}_{4} ; \mathrm{N}_{0} \mathrm{P}_{2} \mathrm{~K}_{0}$ solution containing $7 \mathrm{mM} \mathrm{Na}_{2} \mathrm{HPO}_{4}$; and $\mathrm{N}_{0} \mathrm{P}_{4} \mathrm{~K}_{0}$ solution containing $14 \mathrm{mM} \mathrm{Na} \mathrm{HPO}_{4}$ ) as described previously (Osuji and Madu 1995, Osuji et al. 1998). Each nutrient treatment induced at least $95 \%$ germination. About 3 to 5 weeks after germination (when the leaves of the control seedlings started to turn yellow), the entire shoots were harvested, immediately frozen with dry ice, ground to powder with pestle and mortar, and stored at $-70{ }^{\circ} \mathrm{C}$. $\mathrm{GDH}$ was extracted from the powdered tissues $(25-30 \mathrm{~g})$ as described before (Osuji and Madu 1995) with $50 \mathrm{~cm}^{3}$ of extraction buffer (Loyola-Vargas and De Jimenez 1984). All the purification steps were carried out at $4{ }^{\circ} \mathrm{C}$. Tissue debris were removed by centrifugation $(4000 \mathrm{~g}$, $15 \mathrm{~min}$ ). The cloudy supernatant was frozen at $-20^{\circ} \mathrm{C}$, and was centrifuged $(10000 \mathrm{~g}, 15 \mathrm{~min})$ after thawing. The crude extract was saturated to $50 \%$ with solid $\left(\mathrm{NH}_{4}\right)_{2} \mathrm{SO}_{4}$ and the resultant precipitate was pelleted by centrifugation $(10000 \mathrm{~g}, 15 \mathrm{~min})$. The pellet was dissolved in a minimum volume of $0.1 \mathrm{M}$ Tris- $\mathrm{HCl}$ buffer, $\mathrm{pH} 8.5$, and dialyzed against 3 changes of $10 \mathrm{mM}$

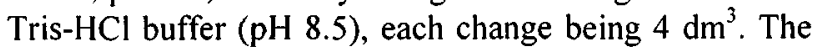
volume of the GDH solution containing about $0.3 \mathrm{~g}$ protein was brought to $\sim 50 \mathrm{~cm}^{3}$ with ice-cold $10 \mathrm{mM}$ Tris- $\mathrm{HCl}$ buffer ( $\mathrm{pH} \mathrm{8.5)}$, and then subjected to Rotofor IEF (Bio-Rad, Hercules, CA, USA) (Osuji and Madu 1995). The 20 Rotofor fractions were collected, their $\mathrm{pH}$ values measured, and then dialyzed as described above.

GDH activities were determined by photometry at $340 \mathrm{~nm}$ (Osuji and Cuero 1992) with $0.4-35.0 \mathrm{mM}$ $\alpha-\mathrm{KG}, 2.0-250.0 \mathrm{mM} \mathrm{NH}_{4} \mathrm{Cl}, 0.16 \mathrm{mM}$ NADH, $1.3 \mathrm{mM}$ $\mathrm{CaCl}_{2}$, and $0.2 \mathrm{~cm}^{3}$ of $\mathrm{GDH}$ solution, in a final reaction induction of the acidic and neutral isoenzymes of GDH by treatment of crops with potassium, phosphorus, and nitrogen nutrients led to the enhancement of crop biomass. In the study, maize and soybeans were selected as the experimental plants because they have been used extensively in studies on the functions of the enzyme (Pryor 1990, Sakakibara et al. 1995, Stewart et al. 1995, Turano et al. 1996, Šukalović and Vuletić 2001) and in the physiology of nutrient uptake (Marschner 1998, Elliott et al. 1984, Jungk et al. 1990).

volume of $3 \mathrm{~cm}^{3}$ per assay. From the initial velocities of the reaction, double reciprocal plots were constructed (Osuji and Cuero 1992). The maximum velocity $\left(\mathrm{V}_{\max }\right)$ was calculated from the replots (Segel 1975) of the $1 / \mathrm{V}$-axis intercepts versus the reciprocals of the $\mathrm{NH}_{4} \mathrm{Cl}$ concentrations. Protein concentrations were determined by the method of Lowry et al. (1951). Enzyme and protein assays were done in triplicate, and the average was calculated.

Equal volumes $\left(0.5 \mathrm{~cm}^{3}\right)$ of the Rotofor fràctions were concentrated 10 -fold by vacuum centrifugation, followed by $7.5 \%$ native PAGE at $4{ }^{\circ} \mathrm{C}$ (Osuji and Madu 1995). $\mathrm{GDH}$ charge isomer (isoenzyme population distribution) pattern was visualized by staining the electrophoresed gel in L-glutamate- $\mathrm{NAD}^{+}$-phenazine methosulphate-tetrazolium blue solution (Cammaerts and Jacobs 1983).

Nutrient treatments: For the soybean crop, a $150 \times 150 \mathrm{~m}$ field plot in the University farm, Waller County was plowed and subdivided into 10 ridges. The 2 border ridges were not used. Soybean seeds inoculated with Bradyrhizobium japonicum were sowed by hand with $4 \mathrm{~cm}$ spacing. The plot was watered immediately to $50 \%$ field capacity, and twice per week. Seedlings were randomly harvested from the 8 ridges (20 seedlings per ridge) 2 weeks after planting, and used for the determination of GDH activity and isoenzyme pattern. The unharvested seedlings were allowed to continue to grow and 8 nutrient treatments were applied, one treatment per ridge. The stock solution of treatment 1 contained $1 \mathrm{~mol} \mathrm{dm}^{-3}$ of each of $\mathrm{NH}_{4} \mathrm{Cl}, \mathrm{KH}_{2} \mathrm{PO}_{4}$ and $\mathrm{Na}_{2} \mathrm{SO}_{4}$; treatment 2 contained $1 \mathrm{~mol} \mathrm{dm}^{-3}$ of each of $\mathrm{NH}_{4} \mathrm{Cl}$ and $\mathrm{Na}_{2} \mathrm{HPO}_{4}$; treatment 3 contained $1 \mathrm{~mol} \mathrm{dm}^{-3}$ of each of $\mathrm{NH}_{4} \mathrm{Cl}$ and $\mathrm{KCl}$, but $0.5 \mathrm{~mol} \mathrm{dm}^{-3}$ of $\mathrm{Na}_{2} \mathrm{~S}_{2} \mathrm{O}_{5}$; treatment 4 contained $1 \mathrm{~mol} \mathrm{dm}^{-3}$ of $\mathrm{KH}_{2} \mathrm{PO}_{4}$ and $2 \mathrm{~mol}$ $\mathrm{dm}^{-3}$ of $\mathrm{NH}_{4} \mathrm{Cl}$; treatment 5 contained $1 \mathrm{~mol} \mathrm{dm}$ of $\mathrm{K}_{2} \mathrm{HPO}_{4}$; treatment 6 contained $1 \mathrm{~mol} \mathrm{dm}{ }^{-3}$ of each of $\mathrm{K}_{2} \mathrm{HPO}_{4}$ and $\mathrm{Na}_{2} \mathrm{~S}_{2} \mathrm{O}_{5}$; and treatment 7 contained $1 \mathrm{~mol} \mathrm{dm}^{-3}$ of each of $\mathrm{Na}_{2} \mathrm{~S}_{2} \mathrm{O}_{5}$ and $\mathrm{NH}_{4} \mathrm{Cl}$. The $8^{\text {th }}$ treatment was the water control. The nutrient treatments and the water control were applied five times 
at $4 \mathrm{~d}$ intervals by diluting $200 \mathrm{~cm}^{3}$ of the stock nutrient solution to $8 \mathrm{dm}^{3}$ with distilled water, and deliver to the base of the soybean with a watering can. The first treatment was applied on the day 18 after planting.

For the maize experiment, 10 pots $\left(20-\mathrm{dm}^{3}\right)$ were filled with the sandy, silt, clay soil collected from the University farm. The pots were arranged on a grass lawn away from any shade. Maize seeds (Zea mays L. hybrid KD-68) were sowed in the pots, seven per pot, and watered three days per week. At 3 weeks after seedling emergence, the entire shoots of four seedlings per pot were harvested and combined to make a single sample. The maize GDH activity and isoenzyme population pattern were determined as described above. The remaining seedlings were allowed to grow in their pots. Five pots were left unfertilized as the control, whilst the remaining 5 were treated with $20 \mathrm{~g}$ of 13:13:13 granular NPK fertilizer per pot. The NPK fertilizer rate was within

\section{Results and discussion}

GDH isoenzyme patterns in response to the treatment of soybean seedlings with nutrients of different NPKS combinations demonstrated a strict dependence on the concentrations of the nutrients (Fig. 1). This pattern was in agreement with previous pattern for the maize (Osuji and Madu 1995, Osuji et al. 1998). The GDH isoenzyme distribution pattern of a plant represents the total but not the average number of isoenzyme bands resulting from the treatment (Osuji and Madu 1995, 1997, Osuji et al. 1998, Osuji and Braithwaite 1999) because crop samples used for the extraction of GDH were not subjected to statistical selection. Therefore, in order to use the GDH isoenzyme patterns to deduce the nutrient status of a crop, the GDH isoenzymes patterns have to be calibrated against known concentrations and combinations of nutrients.

The GDH isoenzymes of the control soybeans (Fig. 1) were focused in Rotofor chambers 8 - 11. Treatment of the potted soybean seedlings with up to $25 \mathrm{mM} \mathrm{NH}_{4} \mathrm{Cl}$ solution induced the formation of 28 isoenzymes in two rows of 14 isoenzymes per row. The $\mathrm{pH}$ values of the Rotofor fractions 4 - 18 were: $5.50,5.96,6.80,7.40,8.03$, $8.43,8.77,9.10,9.97,10.22,10.60,11.10,11.30,11.40$, and 12.00. Treatment with higher concentrations of $\mathrm{NH}_{4} \mathrm{Cl}$ suppressed the $\mathrm{GDH}$ isoenzymes. With $50 \mathrm{mM}$ $\mathrm{NH}_{4} \mathrm{Cl}$, there were only 5 isoenzymes and they focused in Rotofor chambers 9 - 13. Treatment of soybean with $5 \mathrm{mM} \mathrm{Na} \mathrm{SO}_{4}$ solution produced $\mathrm{GDH}$ isoenzymes in Rotofor chambers 6 - 14, but with $25 \mathrm{mM} \mathrm{Na}_{2} \mathrm{SO}_{4}$ 28 isoenzymes were produced in two rows similar to the pattern induced by $25 \mathrm{mM} \mathrm{NH}_{4} \mathrm{Cl}$ treatment. Higher concentrations of $\mathrm{Na}_{2} \mathrm{SO}_{4}$ suppressed the $\mathrm{GDH}$ isoenzymes. Treatment with up to $50 \mathrm{mM} \mathrm{Na} \mathrm{NPO}_{4}$ the range recommended for vegetable growth by the manufacturer (Howard Johnson, Milwaukee, WI, USA). The fertilizer was applied as top dressing to the pots $24 \mathrm{~d}$ after emergence. All pots including the controls were watered twice per week.

Monitoring the GDH response: Soybean leaf samples $(\sim 40 \mathrm{~g})$ were collected from each of the 8 treatments 7 weeks after planting. On the other hand, maize leaf samples were randomly collected at $40,60,80$, and $110 \mathrm{~d}$ after emergence, one leaf (leaf 4,5 , or 6) from a plant, leaves from replicate pots being combined to make one sample. All leaf samples were immediately frozen with dry ice, ground to powder, and stored at $-70^{\circ} \mathrm{C}$ for further use for GDH assay and isoenzyme analysis. At maturity, the maize seeds and soybean shoots were harvested, air dried, and weighed.

induced only about 10 isoenzymes, but higher concentrations of $\mathrm{Na}_{2} \mathrm{HPO}_{4}$ induced 28 isoenzymes in 2 rows similar to those induced by $25 \mathrm{mM} \mathrm{NH}_{4} \mathrm{Cl}$, and $25 \mathrm{mM} \mathrm{Na} \mathrm{SO}_{4}$ solutions. Therefore, the GDH isoenzymes induced by $25 \mathrm{mM} \mathrm{NH}_{4} \mathrm{Cl}, 25 \mathrm{mM} \mathrm{Na}_{2} \mathrm{SO}_{4}$, and $100 \mathrm{mM} \mathrm{Na} \mathrm{HPO}_{4}$ treatments were similar because they fluctuated on the two rows. Treatment of soybean with low concentration $(5 \mathrm{mM})$ of $\mathrm{KCl}$ solution alone suppressed the GDH isoenzymes thus indicating the sensitivity of the crop to the nutrient.

GDH isomerization curve: The $V_{\max }$ values of the enzyme isomerization increased curvilinearly as the inorganic phosphate concentration decreased (Table 1, a non-competitive inhibition kinetics), similarly to the isomerization curve obtained for maize (Osuji et al. 1998). The curvilinear response suggested the restriction of crop metabolism and GDH activity under excess phosphate supply because in the soybean, a decrease of the applied phosphate from 50 to $0 \mathrm{mM}$ increased the $\mathrm{V}_{\max }$ values by $100 \%$, but a decrease from $100-50 \mathrm{mM}$ merely increased the $\mathrm{V}_{\max }$ values by $33 \%$. In maize also, a decrease in the applied phosphate from 7 to $0 \mathrm{mM}$ increased the $\mathrm{V}_{\max }$ value by $100 \%$, but a decrease from 14 to $7 \mathrm{mM}$ merely increased the $\mathrm{V}_{\max }$ values by $50 \%$ (Osuji et al. 1998). The curvilinear response of the enzyme activity to the applied phosphate is analogous to and a reflection of the dependence of the enzyme activity on pH gradients (Osuji and Madu 1996) because the enzyme's $V_{\max }$ value is a function of its electrochemical potential. The limitation imposed on the crop metabolism by GDH may be due to increased fragmentation of the subunits of the enzyme (Osuji et al. 1999, 2001) at high 
mineral ion (nucleophile) concentrations (Fig. 1). The impact of mineral nutrients on the GDH activities might have been exerted via the redox stress by the electrochemical potentials of the cells associated with nutrient transport. This result suggests that the function of GDH is dependent on the isoenzyme distribution pattern, the greater the fragmentation of the subunits, the lower were the $V_{\max }$ values. Because it covers the range of the responses of a crop's GDH to the spectrum of nutrient concentrations and combinations with inorganic phosphate that support the crop's normal metabolism
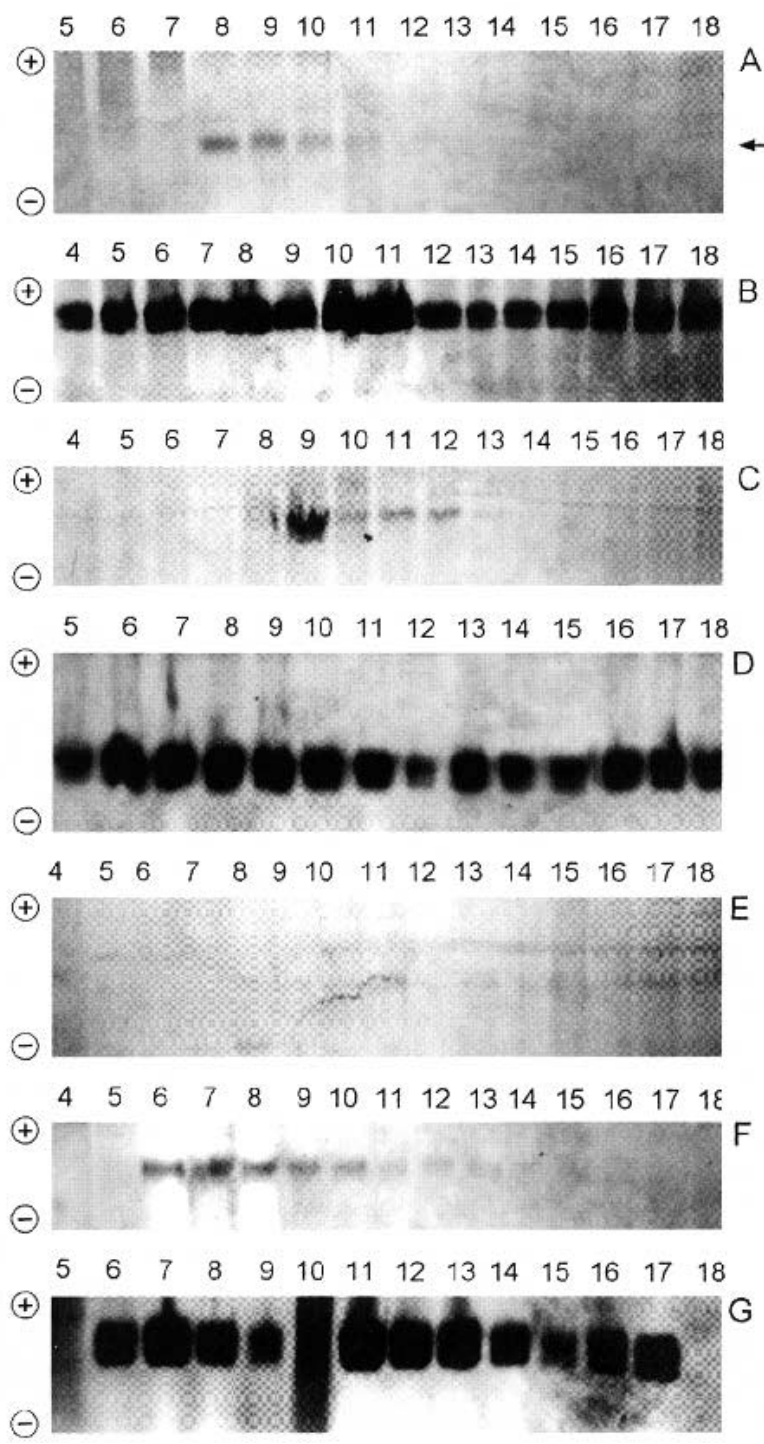

Fig. 1. GDH isoenzyme patterns in response to treatment of soybean with $\mathrm{N}, \mathrm{P}$, and $\mathrm{S}$ nutrients. The GDH extracted from soybean seedlings under each nutrient treatment was Rotoforated, followed with native PAGE. GDH isoenzyme distribution patterns were visualized by staining the electrophoresed gel with tetrazolium blue reagent. $A$ - control, $B$ - $25 \mathrm{mM} \mathrm{NH}_{4} \mathrm{Cl}, C$ - $50 \mathrm{mM} \mathrm{NH}_{4} \mathrm{Cl}, D-25 \mathrm{mM} \mathrm{Na}_{2} \mathrm{SO}_{4}, E$ $50 \mathrm{mM} \mathrm{Na}_{2} \mathrm{SO}_{4}, F-50 \mathrm{mM} \mathrm{Na}_{2} \mathrm{HPO}_{4}, G-100 \mathrm{mM} \mathrm{Na}_{2} \mathrm{HPO}_{4}$
(Osuji et al. 1998), the GDH isomerization curve is useful for identifying inadequate/toxic nutrient supply in plants. The $\mathrm{GDH} \mathrm{K}_{\mathrm{m}}$ values did not respond systematically to the nutrient treatments of the seedlings (Table 1) probably because the enzyme interacts with a multitude of nucleophiles as substrates of low specificity.

GDH isomerization during crop growth: The GDH pattern of the unfertilized soybean (Fig. $2 A$ ) was similar to those induced by $50 \mathrm{mM} \mathrm{Na} \mathrm{HPO}_{4}, 50 \mathrm{mM} \mathrm{NH}{ }_{4} \mathrm{Cl}$, and about $40 \mathrm{mM} \mathrm{Na}_{2} \mathrm{SO}_{4}$ treatments, the difference being that in the unfertilized seedlings, the acidic GDH

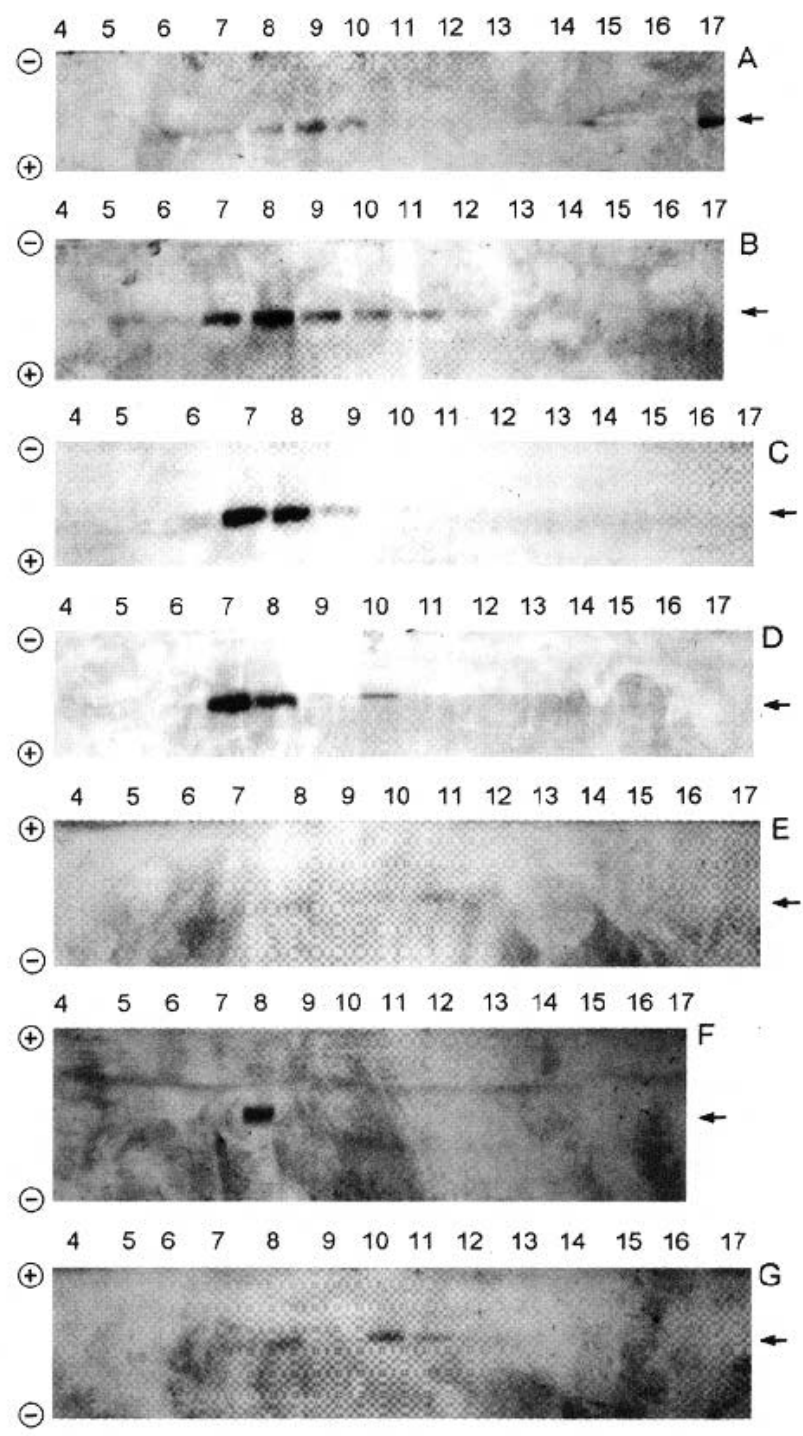

Fig. 2. Response of GDH to treatment of soybeans with nutrients of different $\mathrm{N}, \mathrm{P}, \mathrm{K}$, and $\mathrm{S}$ compositions. The GDH extracted from the leaves of field grown soybean under each nutrient treatment was subjected to IEF, followed with native PAGE. GDH isoenzyme distribution patterns were visualized by staining the electrophoresed gel with tetrazolium blue reagent. $A$-control soybeans, $B$ - soybeans treated with NKPS (treatment 1), $C$ - NP (treatment 2), D - NKS (treatment 3), $E-$ NKP (treatment 4), $F-$ KP (treatment 5 ), and $G-$ KPS (treatment 6). 
isoenzymes (Rotofor fractions 5 - 7) were induced. Soybean is normally fertilized with PK nutrients.

The control (treatment 8) soybean GDH isoenzyme pattern at 7 weeks after planting (transition from the vegetative to the reproductive state) did not change from that of the control unfertilized seedlings (Fig. 2A). This suggested that the basal nutrient condition which included soil moisture, nutrient concentrations and composition that affected the GDH in the unfertilized seedlings did not change during 7 weeks after seed planting. Also the basic isoenzymes of GDH were suppressed by all the nutrient treatments in the field thus showing that the nutrient levels available to the crop were different from $25 \mathrm{mM}$ $\mathrm{NH}_{4} \mathrm{Cl}, 25 \mathrm{mM} \mathrm{Na}_{2} \mathrm{SO}_{4}$, and $100 \mathrm{mM} \mathrm{Na}_{2} \mathrm{HPO}_{4}$ (Fig. 1) that induced the complete set of soybean $\mathrm{GDH}$ isoenzymes. It was not possible to differentiate one soybean treatment from the other based on visual inspection because the vegetative growth of all the 8 experimental soybeans was equally good. The cv. Donegal is a vegetative-type of soybean because it flowered, but did not produce pods. Soybean treatments 1 - 4 induced the neutral and acidic GDH isoenzymes (Figs. $2 B-D$ ) similar to the control soybean seedlings although some of the isoenzyme bands were lower in intensity than the bands induced by treatment 1 (Fig. $2 B$ ). Treatment 5 without $\mathrm{N}$ and $\mathrm{S}$ (Fig. $2 F$ ), treatment 6 without N (Fig. 2G), and treatment 7 without $P$ and $K$ (Fig. not shown) suppressed virtually all the GDH isoenzymes, thereby supporting the results in Fig. $2 A-E$. In particular, treatments $1-4$ with favourable NPKS ratios for soybean induced the acidic and neutral GDH isoenzymes.

Except the control soybean and soybean treatments 1 - 4, the GDH isomerization $V_{\max }$ values (Table 1) for the other field soybeans were too low to be measured accurately by photometry thus confirming the virtual absence of the isoenzyme patterns from those soybeans. The soybean GDH activities (Table 1) were normal because they fell within the range reported by Turano et al. (1996).

Values of $V_{\max }$ (Table 1) that were below the isomerization curve indicated nutrient inadequacy, and/or imbalance because the isomerization curve covers the responses of the crop's GDH to the spectrum of nutrient concentrations and combinations that support the crop's normal metabolism. The importance of the curve is that it guides the proper interpretation of the GDH isoenzyme patterns.

The GDH isoenzyme pattern for the maize without nutrients (Fig. 3A) showed similarity to that induced by $7 \mathrm{mM} \mathrm{Na}_{2} \mathrm{HPO}_{4}$ (Osuji et al. 1998) treatment. Analysis of the maize leaf GDH isoenzyme patterns 40 DAE (transition from vegetative to the reproductive phase) (Fig. $3 B$ ) showed the induction of the row 4 acidic GDH

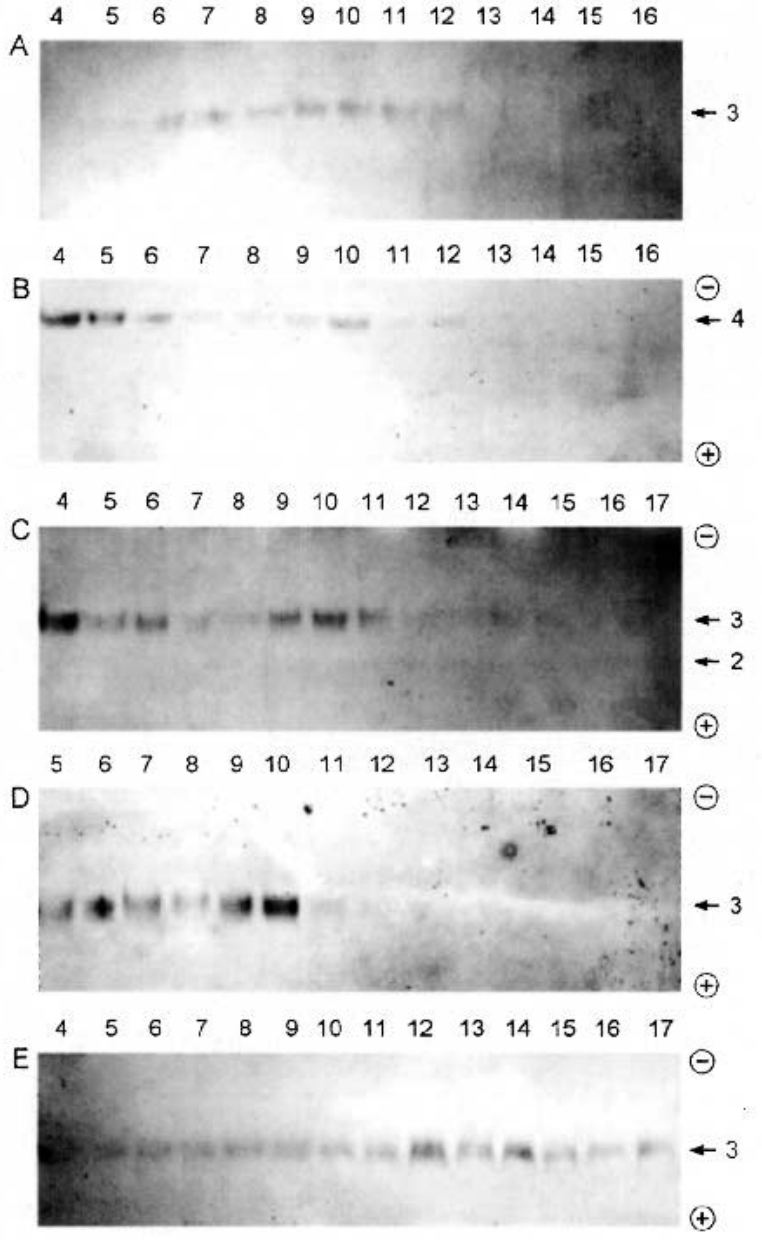

Fig. 3. Monitoring the response of GDH to nutrient changes during maize maturity. The GDH extracted from the leaves at each stage of maize growth was subjected to IEF, followed with native PAGE. GDH isoenzyme distribution pattern was visualized by staining the electrophoresed gel with tetrazolium blue reagent. $A-20 \mathrm{DAE}$, no fertilization, $B-40 \mathrm{DAE}$, $C$ - 60 DAE, $D$ - 80 DAE, $E-110$ DAE.

isoenzymes but more suppression of the neutral and basic isoenzymes typical of the patterns induced by NK nutrient treatment (Osuji et al. 1998). But the GDH isoenzyme pattern for the control maize remained the same as it was at $20 \mathrm{DAE}$. The GDH isoenzyme pattern for the control maize was therefore the baseline control. The change in GDH isoenzyme pattern consequent upon the fertilization of the maize showed that the signals from the basal nutrient level were superceded by those from the applied nutrients. Analysis of the maize leaf GDH isoenzyme patterns 60 DAE showed pronounced induction of the row 3 acidic and neutral isoenzymes (Fig. 3C) for the fertilized maize, but the GDH pattern for the control maize remained the same as it was at $20 \mathrm{DAE}$. The GDH isoenzyme pattern (Fig. $3 \mathrm{C}$ ) was typical of the calibrated $\mathrm{GDH}$ isoenzyme pattern induced by $50-75 \mathrm{mM} \mathrm{NH}_{4} \mathrm{Cl}$ 
(Osuji and Madu 1995). The isoenzyme pattern at 60 DAE therefore superceded that at $40 \mathrm{DAE}$. The change represented the nutrient remobilization occurring in the period during the development of maize seeds.

The GDH isoenzyme pattern for the fertilized maize (Fig. $3 D$ ) was virtually the same at $80 \mathrm{DAE}$ as at $60 \mathrm{DAE}$, while the GDH pattern for the control maize remained the same as that at $20 \mathrm{DAE}$. At $110 \mathrm{DAE}$, the fertilized maize exhibited a GDH pattern (Fig. $3 E$ ) in which all the row 3 acidic and basic isoenzymes were present typical of the standard maize GDH induced by $100 \mathrm{mM} \mathrm{NH}_{4} \mathrm{Cl}$ (Osuji and Madu 1995). At $110 \mathrm{DAE}$, the maize seeds had matured. Therefore, there was an increase in the leaf $\mathrm{N}$ nutrient content from 75 to $100 \mathrm{mM}$ after seed development. The increased $\mathrm{N}$ could have resulted from senescence-related hydrolytic processes (Watanabe et al. 1989) taking place in the leaves. Therefore as in the case of avocado fruit ripening (Loulakakis et al. 1994), changes in maize GDH isoenzyme pattern associated with plant metabolism at the vegetative and reproductive stages were different from those resulting from the senescence period. The GDH isoenzyme bands were undetectable in the control maize at 110 DAE probably because the maize leaves had become yellow at that stage.

The maize GDH $V_{\max }$ values (Table 2) fitted into the inorganic phosphate concentration range of the isomerization curve unlike the GDH $V_{\max }$ values of soybean that fell outside the curve. The values of the maize kinetic constants were normal because they fell within the range reported earlier (Osuji and Madu 1996). The baseline $V_{\max }$ value was $138.9 \mu \mathrm{mol} \mathrm{m} \mathrm{mg}^{-1} \mathrm{~min}^{-1}$ at $20 \mathrm{DAE}$. The $\mathrm{V}_{\max }$ increased from the baseline value to $256.4 \mu \mathrm{mol} \mathrm{mg} \mathrm{min}^{-1}$ at $40 \mathrm{DAE}$ showing that the signals from the basal nutrient concentration were overridden by those from the applied nutrients. The basal nutrient concentration included the residual nutrient combination and concentration in the soil from previous seasons, and soil water content in relation to soil physical properties. Similar increases in the GDH activity of maize treated with $\mathrm{NH}_{4} \mathrm{NO}_{3}$ have been reported (Ribaudo et al. 2001). GDH integrates all the multitude of signals in the soil to give one signal expressed as the isomerization $\mathrm{V}_{\max }$ value and the isoenzyme pattern (Osuji et al. 1998, Osuji and Braithwaite 1999). Where nutrients were not applied, the $V_{\max }$ remained low throughout crop maturity and there was no seed development.

The pre-harvest GDH $\mathrm{V}_{\max }$ values (Tables 1 and 2) demonstrated the importance of the unfertilized control crop in the proper interpretation of the GDH isoenzyme patterns. GDH responds to the ambient environmental

Table 1. GDH kinetic constants and biomass of soybeans treated with nutrients of different N, P, K, and S compositions.

\begin{tabular}{lccc}
\hline Treatments & $\begin{array}{l}\mathrm{V}_{\max } \\
{\left[\mathrm{mmol} \mathrm{g}^{-1} \mathrm{~min}^{-1}\right]}\end{array}$ & $\begin{array}{l}\mathrm{K}_{\mathrm{m}} \\
{[\mathrm{mM}]}\end{array}$ & $\begin{array}{l}\text { Biomass } \\
{[\mathrm{kg}(\mathrm{d} . \mathrm{m} .) \text { plant }}\end{array}$ \\
\hline Control Seedlings & $310.0 \pm 25.1$ & $25.0 \pm 1.3$ & - \\
$100 \mathrm{mM} \mathrm{Na}_{2} \mathrm{HPO}_{4}$ (seedlings) & $117.0 \pm 9.8$ & $66.7 \pm 4.4$ & - \\
$75 \mathrm{mM} \mathrm{Na}_{2} \mathrm{HPO}_{4}$ (seedlings) & $126.1 \pm 6.3$ & $74.8 \pm 6.1$ & - \\
$50 \mathrm{mM} \mathrm{Na}_{2} \mathrm{HPO}_{4}$ (seedlings) & $154.0 \pm 11.2$ & $83.3 \pm 5.9$ & - \\
$35 \mathrm{mM} \mathrm{Na}_{2} \mathrm{HPO}_{4}$ (seedlings) & $204.0 \pm 6.6$ & $78.5 \pm 5.4$ & - \\
$25 \mathrm{mM} \mathrm{Na}_{2} \mathrm{HPO}_{4}$ (seedlings) & $236.0 \pm 12.3$ & $122.0 \pm 8.8$ & - \\
$10 \mathrm{mM} \mathrm{Na}_{2} \mathrm{HPO}_{4}$ (seedlings) & $280.0 \pm 9.4$ & $67.9 \pm 7.3$ & - \\
$50 \mathrm{mM} \mathrm{NH}_{4} \mathrm{Cl}$ (seedlings) & $400.0 \pm 31.8$ & $500.0 \pm 25.0$ & - \\
$25 \mathrm{mM} \mathrm{NH}_{4} \mathrm{Cl}$ (seedlings) & $182.0 \pm 13.7$ & $125.0 \pm 8.4$ & 2.02 \\
$5 \mathrm{mM} \mathrm{NH}{ }_{4} \mathrm{Cl}$ (seedlings) & $400.4 \pm 9.3$ & $45.0 \pm 4.8$ & 2.53 \\
Before nutrient application & $145.6 \pm 11.2$ & $78.4 \pm 6.9$ & 2.88 \\
Field reatment (control) & $118.0 \pm 8.1$ & $25.0 \pm 1.2$ & 2.49 \\
Field treatment (NPKS) & $130.0 \pm 8.6$ & $20.8 \pm 1.5$ & 3.03 \\
Field treatment (NP) & $56.0 \pm 3.0$ & $25.0 \pm 1.7$ & - \\
Field treatment (NKS) & $22.0 \pm 1.8$ & $11.1 \pm 0.5$ & $12.5 \pm 1.8$ \\
Field treatment (NPK) & $23.9 \pm 2.1$ & $12.5 \pm 1.8$ & - \\
\hline
\end{tabular}

Table 2. GDH $\mathrm{V}_{\max }\left[\mathrm{mmol} \mathrm{g}{ }^{-1} \mathrm{~min}^{-1}\right]$ values at different DAE and seed biomass [g plant ${ }^{-1}$ ] of maize as affected by NPK (nutrient treatments were not applied at $20 \mathrm{DAE}$ ).

\begin{tabular}{|c|c|c|c|c|c|c|}
\hline Treatments & $20 \mathrm{DAE}$ & $40 \mathrm{DAE}$ & $60 \mathrm{DAE}$ & $80 \mathrm{DAE}$ & $110 \mathrm{DAE}^{-}$ & Seed mass \\
\hline NPK & - & $256.4 \pm 10.3$ & $\begin{array}{r}161.3 \pm 7.2 \\
714+3.7\end{array}$ & $\begin{array}{l}156.3 \pm 3.3 \\
0\end{array}$ & $\begin{array}{l}151.5 \pm 2.4 \\
0\end{array}$ & $\begin{array}{l}27.0 \pm 1.4 \\
\text { no seeds }\end{array}$ \\
\hline
\end{tabular}


conditions of plants (Barash et al. 1975, Lauriere et al. 1981, Hartmann 1982, Yamaya et al. 1984, Srivastava and Singh 1987, Magalhaes 1991, Osuji 1997). The control unfertilized crops did not differentiate the effects of the environment from those of the applied nutrients because it is not possible to subtract the GDH isoenzyme patterns and the values of the GDH kinetic constants of the control crop from those of the fertilized crops. Rather, it was the GDH kinetics and isoenzyme pattern of the unfertilized control that delineated the effects of the applied nutrients from the effects of the environment. Therefore, the unfertilized plant was just like any treatment of the plants, the main difference being that no additional nutrients were applied.

GDH isomerization and biomass enhancement: Biomass increases in the soybean were expressed on the basis of shoot dry mass, but seed dry mass was used in the case of maize. The dry mass yields of soybean shoots per treatment were $2.02,2.53,2.88,2.49,3.05,1.41,1.89$, and $1.80 \mathrm{~kg}$ for the control and treatments 1 to 7 , respectively. Treatments $1-4$ gave yields $25-50 \%$ (average of $2.74 \pm 0.27 \mathrm{~kg}$ per ridge) higher than the control. They were the soybeans that gave only the acidic and neutral GDH isoenzymes (Fig. 2). Nutrient treatments 1- 4 were also the tests for the adequacy of the conventional soybean fertilizer composition, and they also gave the highest yield. The biomasses produced from treatments $5-7$ were lower $(1.70 \pm 0.26 \mathrm{~kg}$ per ridge) than those from treatments $1-4$, and were about $30 \%$ lower than that of the control. Treatments $5-7$ also suppressed the soybean GDH isoenzymes. Therefore, $\mathrm{GDH}$ isomerization preceded biomass enhancement because the soybean biomass increased after the acidic and neutral GDH isoenzyme had been induced, but decreased after they were suppressed.

The control maize tasseled, but the ears failed to bear any seeds. Therefore, the residual nutrients available prior to nutrient application was insufficient for sustaining the reproductive phase of maize. On the other hand, each maize plant treated with NPK (13:13:13) nutrient developed one ear, with a yield of $27.0 \pm 1.4 \mathrm{~g}$ (seeds) plant $^{-1}$. Therefore as in the soybean, the maize yield increased after the acidic and neutral GDH isoenzymes had been induced by nutrients. The failure of the control maize to develop seeds was probably due to the inability of the $3^{\text {rd }}$ row neutral GDH isoenzyme pattern at $20 \mathrm{DAE}$ to change to the $4^{\text {th }}$ row acidic and neutral isoenzyme pattern at $40 \mathrm{DAE}$. The interphase between the vegetative and reproductive stages in maize is around 40 DAE. The acidic and neutral isoenzymes being the biomass-related isoenzymes were simultaneously induced at the beginning of that interphase. This again shows that biomass was enhanced in response to the induction of specific GDH isoenzyme population pattern.

The physiological function of GDH may therefore reside in the differential charge gradients of its isoenzymes. In the soybean, all the GDH isoenzyme patterns that corresponded to the increased biomass possessed the neutral and acidic isoenzymes, but lacked the basic isoenzymes (Fig. 2). Also the treatment of maize with fertilizer induced the neutral and acidic isoenzymes of GDH while suppressing the basic isoenzymes (Fig. 3), with concomitant production of seeds. Therefore, the biomass enhancement associated with GDH (Ameziane et al. 2000, Osuji and Madu 1997) could be a function performed by the cooperation of its neutral and acidic isoenzymes. The relationship between GDH isomerization $\mathrm{V}_{\max }$ and phosphate concentration on one hand, and between biomass enhancement and the acidic and neutral isoenzymes on the other hand suggests that the enzyme could be a useful molecular marker for preharvest monitoring of the biomass response of a plant to the applied fertilizer.

\section{References}

Ameziane, R., Bernhard, K., Lightfoot, D.: Expression of bacterial gdhA gene encoding a NADPH glutamate dehydrogenase in tobacco affects plant growth and development. - Plant Soil 221: 47-57, 2000.

Barash, L., Mor, H., Sadon, T.: Evidence for ammoniumdependent de novo synthesis of glutamate dehydrogenase in detached oat leaves. - Plant Physiol. 56: 856-858, 1975.

Cammaerts, E., Jacobs, M.A.: A study of the polymorphism and the genetic control of the glutamate dehydrogenase isoenzyme in Arabidopsis thaliana. - Plant Sci. Lett. 31: 67 73, 1983.

Duke, S.H., Friedrich, J.W., Schrader, L.E., Koukkari, W.L: Oscillations in the activities of enzymes of nitrate reduction and ammonia assimilation in Glycine max and Zea mays. Plant Physiol. 42: 269-276, 1978.

Elliott, G.C., Lynch, J., Låuchli, A.: Influx and efllux of

phosphate in roots of intact maize plants. - Plant Physiol. 76: 336-341, 1984.

Hartmann, T.: Ammonium assimilation and nitrogen partitioning. - In: Ellenberg, H., Esser, K., Kubitzki, K., Schnepf, E., Ziegler, H. (ed.): Progress in Botany. Vol. 4. Pp. 154-164. Springer-Verlag, Berlin 1982.

Hřib, J., Vooková, B., Kormuták, A.: Biochemical differences between normal callus and embryogenic suspensor mass of silver fir. - Biol. Plant. 39: 507-513, 1997.

Jail, A.J., Shargool, P.D.: Use of an aneuploid soybean cell culture to examine the relative importance of the GS:GOGAT system and GDH in ammonia assimilation. - J. Plant Physiol. 130: 137-146, 1987.

Jail, A.J., Srivastava, H.S.: Effect of salicylic acid on nitrate reductase and glutamate dehydrogenase activities in maize roots. - Physiol. Plant. 53: 285-288, 1981. 
Jungk, A., Asher, C.J., Edwards, D.G., Meyer, D.: Influence of phosphate status on phosphate uptake kinetics of maize (Zea mays) and soybeans (Glycine max). - Plant Soil 124: 175-182, 1990.

King, J., Wu, W.Y.: Partial purification and kinetic properties of glutamate dehydrogenase from soybean cotyledons. Phytochemistry 10: 915-928, 1971.

Lauriere, C., Wiesman, N., Daussant, J.: Glutamate dehydrogenase in the first leaf of wheat. - Physiol. Plant. 52: 146-150, 1981.

Lightfoot, D.A., Baron, A., Wootton, J.C.: Expression of $E$. coli glutamate dehydrogenase in the cyanobacterium Synechococcus PCC6301 causes ammonia tolerance. - Plant mol. Biol. 11: 191-202, 1988.

Loulakakis, K.A., Roubellakis-Angelakis, K.A., Kanellis, A.K.: Regulation of glutamate dehydrogenase and glutamine synthetase in avocado fruit during development and ripening. - Plant Physiol. 106: 217-222, 1994.

Loyola-Vargas, V.M., De Jimenez, E.S.: Differential role of glutamate dehydrogenase in nitrogen metabolism of maize tissue. - Plant Physiol. 76: 536-540, 1984.

Lowry, O.H., Rosebrough, N.J., Farr, A.L., Randall, R.J.: Protein measurement with the Folin phenol reagent. - J. biol. Chem. 139: 256-275, 1951 .

Magalhaes, J.R.: Kinetics of ${ }^{15} \mathrm{NH}_{4}^{+}$assimilation in tomato plants: Evidence for ${ }^{15} \mathrm{NH}_{4}{ }^{+}$assimilation via GDH in tomato roots. - J. Plant Nutr. 14: 1341-1353, 1991

Marschner, H.: Mineral Nutrition of Higher Plants. - Academic Press, New York 1998.

Melo-Oliveira, R., Oliveira, LC., Coruzzi, G.M.: Arabidopsis mutant analysis and regulation define a nonredundant role for glutamate dehydrogenase in nitrogen assimilation. Proc. nat. Acad. Sci. USA 93: 4718-4723, 1996.

Osuji, G.O.: Peanut glutamate dehydrogenase: A target site of herbicide action. - In: Ando, T., Fujita, K., Mae, T., Matsumoto, H., Mori, S., Sekiya, J. (ed): Plant Nutrition for Sustainable Food Production and Environment. Pp. 845850. Kluwer Academic Press, Dordrecht 1997.

Osuji, G.O., Braithwaite, C.: Signaling by glutamate dehydrogenase in response to pesticide treatment and nitrogen fertilization of peanut (Arachis hypogaea L.). - J. agr. Food Chem. 47: 3332-3344, 1999.

Osuji, G.O., Braithwaite, C., Pointer, R., Reyes, J.: Pesticide inactivation of peanut glutamate dehydrogenase: Biochemical basis of the enzyme's isomerization. - J. agr. Food Chem. 47: 3345-3351, 1999.

Osuji, G.O., Cuero, R.G.: Regulation of ammonium ion salvage and enhancement of the storage protein contents of corn, sweet potato, and yam tuber by $\mathrm{N}$-(carboxymethyl)chitosan application.- J. agr. Food Chem. 40: 724-734, 1992.

Osuji, G.O., Madu, W.C.: Ammonium ion-dependent isomerization of glutamate dehydrogenase in relation to glutamate synthesis in maize. - Phytochemistry 39: 495-503, 1995.

Osuji, G.O., Madu, W.C.: Ammonium ion salvage by glutamate dehydrogenase during defense response in maize. Phytochemistry 42: 1491-1498, 1996.

Osuji, G.O., Madu, W.C.: Regulation of sweet potato growth and differentiation by glutamate dehydrogenase. - Can. J. Bot. 75: 1070-1078, 1997.
Osuji, G.O., Mangaroo, A.S., Roberts, P.S.: In vitro isomerization of glutamate dehydrogenase in relation to phytosequesteration of lead. - SAAS Bull. Biochem. Biotech. 14: 60-72, 2001.

Osuji, G.O., Reyes, J.C., Mangaroo, A.S.: Glutamate dehydrogenase isomerization: A simple method for diagnosing nitrogen, phosphorus, and potassium sufficiency in maize (Zea mays L.). - J. agr. Food Chem. 46: 2395 2401, 1998.

Pryor, A.: A maize glutamic dehydrogenase null mutant is cold temperature sensitive. - Maydica 35: 367-372, 1990.

Ribaudo, C.M., Rondanini, D.P., Cura, J.A., Fraschina, A.A.: Response of Zea mays to the inoculation with Azospirillum on nitrogen metabolism under greenhouse conditions. Biol. Plant. 44: 631-634, 2001.

Robinson, S.A., Stewart, G.R., Phillips, R.: Regulation of glutamate dehydrogenase in plant nitrogen metabolism. Plant Physiol. 95: 509-516, 1992.

Sakakibara, H., Fujii, K., Sugiyama, T.: Isolation and characterization of a cDNA that encodes maize glutamate dehydrogenase. - Plant Cell Physiol. 36: 789-797, 1995.

Segel, L.H.: Biochemical Calculations. $2^{\text {nd }}$ Edition. - John Wiley, New York 1975.

Singh, R.P., Srivastava, H.S.: Glutamate dehydrogenase activity and assimilation of inorganic nitrogen in maize seedlings. Biochem. Physiol. Pflanz. 177: 633-642, 1982.

Srivastava, H.S., Singh, R.P.: Role and regulation of L-glutamate dehydrogenase activity in higher plants. Phytochemistry 26: 597-610, 1987.

Stewart, G.R., Shatilov, V.R., Turnbull, M.H., Robinson, S.A., Goodall, R.: Evidence that glutamate dehydrogenase plays a role in the oxidative deamination of glutamate in seedlings of Zea mays. - Aust. J. Plant Physiol. 22: 805-809, 1995.

Šukalović, V.H.: Properties of glutamate dehydrogenase from developing maize endosperm. - Physiol. Plant. 80: 238-242, 1990.

Sukalović, V.H., Vuletić, M.: Heterogeneity of maize root mitochondria from plants grown in the presence of ammonium. - Biol. Plant. 44: 101-104, 2001.

Turano, F.J., Dashner, R., Upadhyaya, A., Caldwell, C.R.: Purification of mitochondrial glutamate dehydrogenase from dark-grown soybean seedlings. - Plant Physiol. 112: 1357-1369, 1996.

Watanabe, A, Kawakami, N., Azumi, Y.: Gene expression in senescing leaves. - In: Osborne, D.J., Jackson, M.B. (ed.): Cell Separation in Plants. Physiology, Biochemistry, and Molecular Biology. Pp. 31-38. Springer-Verlag, Berlin 1989.

Watanabe, M., Hanamoto, T., Watanabe, Y.: Changes in the activities of ammonia assimilation enzymes during senescence of Brassica napus leaf protoplasts. - In: Ando, T., Fujita, K., Mae, T., Matsumoto, H., Mori, S., Sekiya, J. (ed.): Plant Nutrition for Sustainable Food Production and Environment. Pp 197-198. Kluwer Academic Press, Dordrecht 1997.

Yamaya, T., Oaks, A., Matsumoto, H.: Characteristics of glutamate dehydrogenase in mitochondria prepared from corn shoots. - Plant Physiol. 76: 1009-1013, 1984.

Zimmerman, M.H.: Transport in phloem.- Annu. Rev. Plant Physiol. 11: 167-190, 1960. 